\title{
Magnetic Resonance Imaging, a New Tool for Neuroendocrine Research in Sheep
}

\author{
Yves Tillet
}

CNRS UMR 7247, IFCE, INRAE, University of Tours, Physiologie de la Reproduction et des Comportements, Nouzilly, France

\section{Keywords}

Magnetic resonance imaging · Neuroendocrinology •

Sheep · Steroid and nervous system

\begin{abstract}
Magnetic resonance imaging (MRI) brain analysis is used in rodents and for clinical investigation in humans, and it becomes also possible now for large animal models studies. Specific facilities are available with clinical scanners and benefit to neuroendocrine investigations in sheep. Sheep has a large gyrencephalic brain and its organization is very similar to primates and human, and among physiological regulations, oestrous cycle of the ewes is similar to women. Therefore, this animal is a good model for preclinical researches using MRI, as illustrated with steroids impact on the brain. New data were obtained concerning the effect of sexual steroids on neuronal networks involved in the control of reproduction and in the influence of sexual steroids on cognition. In addition to the importance of such data for understanding the role of these hormones on brain functions, they give new insights to consider the sheep as a powerful model for preclinical studies in the field of neuroendocrinology. These points are discussed in this short review.

(c) 2022 S. Karger AG, Basel
\end{abstract}

\section{Introduction}

For several years, brain imaging appears to be a promising approach to study neuroendocrine interactions for research purposes as illustrated in the control of reproduction in human. Magnetic resonance imaging (MRI) and 2-Deoxy Glucose positron electron tomography imaging were used to demonstrate the effect of oestrogen on the metabolic changes and cognition in menopausal and postmenopausal women $[1,2]$ and the oestrogen negative feedback in the mediobasal hypothalamus $(\mathrm{MBH})$ in healthy women [3]. The effect of sex steroids in neuronal plasticity in the human hypothalamus were also studied during artificial menstrual cycle induced by oral contraceptive pills in young woman [4].

However, the MRI studies were mainly observational and, even though in vivo imaging is safe and non-invasive, the possibility of deeper experimental investigations remains limited in human for ethical reasons. Small individual sample size, heterogeneity of the groups of subjects according to age, hormonal status, etc., make difficult the interpretation of the data. Numerous studies were also performed on laboratory animals, mainly rodents, which present a wide range of genetically modified models. 
Table 1. Comparison of some physiological features between sheep, human, and rodents

\begin{tabular}{llll}
\hline & Sheep & Human & Rodent \\
\hline Body weight, $\mathrm{kg}$ & $60-75$ & 70 & $0.02-0.5$ \\
Brain weight, g & $100-150$ & 1,400 & $0.5-2.4$ \\
Cortical development & Gyrencephalic & Gyrencephalic & Lissencephalic \\
Pituitary morphology & Long pituitary stalk & Long pituitary stalk & Short pituitary stalk \\
Hormonal kinetics with large volume blood samples & Yes & Yes but with ethical concerns No & No \\
Successive cerebral fluid sampling & Yes ethical concerns & No \\
Duration of oestrus cycle, days & $18^{*}$ & 28 & 4 \\
Newborns at birth & $1-3$ & 1 & $6-10$ \\
Weight at birth, kg & $2.5-5$ & $2.5-4.3$ & $0.005-0.010$ \\
\hline
\end{tabular}

* Similar length of luteal phase

However, the physiological characteristics of these species are really different from human ones regarding reproduction and brain morphology. They have a gyrencephalic brain like human and a similar body size. Rodent reproduction is characterized by short oestrus cycles and a high ovulation rate, and has a smooth brain. Large animals like sheep are more suitable animal models for the neuroendocrine study of human reproduction. Ewes have a low ovulation rate (1-3 oocytes/oestrous cycle) and most of the breeds give birth to only 1-3 newborns. The length of the oestrus cycle of the ewe, especially the luteal phase, is very similar to those of woman (Table 1). This short review will thus focus of the use of MRI for studying neuroendocrine control of reproduction and cognition, in sheep, as a large animal model suitable for preclinical research.

\section{MRI in Large Animals}

MRI uses a high magnetic field that aligns the magnetic spin of hydrogen atoms in the tissue in a low energy configuration. The spins are then excited out of equilibrium by a radiofrequency pulse. When the magnetic field is switch off, the spin of hydrogen return to equilibrium (relaxation phase), and the time constants T1 (longitudinal magnetization) and T2 (transverse magnetization) can be measured. These values are used to construct MR images, and because relaxation times differ across tissues, numerous details of the tissue can be observed with a high spatial resolution, similar to a histologic section. Therefore, this method is particularly suitable for rich water biological tissue like the brain which contains $75-80 \%$ of water.

MRI in large animal is now available according to the wide range of imaging facilities developed in the past de- cade in most of European countries. Most of them are equipped with $3 \mathrm{~T}$ MRI scanner similar to those used in clinics and suitable for animal such as sheep or pig, similar in size and weight to human [5].

Anatomical MRI scanning last for several minutes, usually between 15 and $20 \mathrm{~min}$ in human, a period during which the body must not move. As it is difficult to avoid any movement and stress induced by the procedure in awake animals, they have to be anaesthetised during scanning. This constraint of long scanning period becomes an advantage for anatomical and fMRI because it allows more signal acquisitions and an increase quality of the picture.

However, anaesthesia is known to alter both neuronal activity and hemodynamic state. During anaesthesia, perception of the stimulus may be reduced if not absent, and the response to the stimulus can be inhibited. The impairment of cellular physiology and neuronal connections could modify the expected physiological response like hormonal secretions in neuroendocrinology. Previous experiments have shown in the ewes that halothane anaesthesia reduced mean plasma Luteinizing Hormone (LH) levels by preventing pulsatile secretion of $\mathrm{LH}$ whereas it has no effect on Follicule-Stimulating Hormone or prolactin [6]. Different results were observed during anaesthesia with pentobarbital, which inhibited LH pulse frequency in luteal phase in intact and in ovariectomized ewes during the breeding season whereas it produced a dramatic, 3-fold increase in LH pulse frequency in intact animals during anoestrous [7]. The corticotropic pituitary-adrenal axis is also stimulated by halothane and to a lesser extent by isoflurane in rabbits [8]. The choice of the anaesthetics is therefore important to study the pattern of hormonal secretion simultaneously with the analysis of brain activation by MRI under general anaesthesia. 

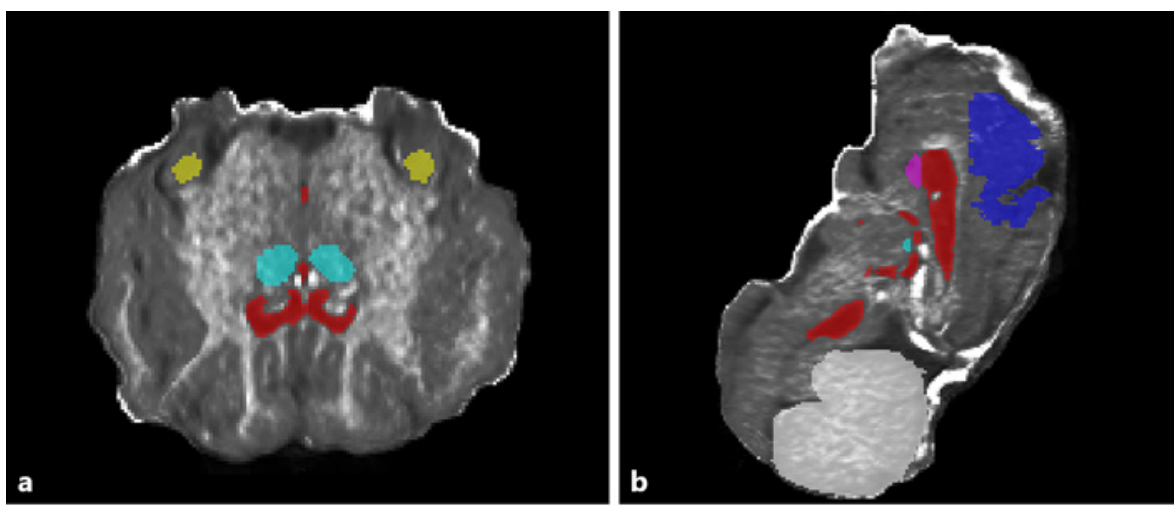

Fig. 1. Atlas - Template and Associated Labels. Segmented atlas showing (1) ventricles, (2) motor cortices, (3) hippocampi, (4) thalami, (5) caudate (6) amygdala, and (7) cerebellum illustrating the transverse (a), parasagittal (b), dorsal planes (d), and 3d rendering of labels on a ventrolateral view with rostral to the left of the image (c). Red, ventricles; green right motor cortex; deep blue, left motor cortex; yellow, hippocampus; light blue, thalamus; purple, caudate nucleus; light pink, amygdala; grey, cerebellum. From Liyanage et al. [20].
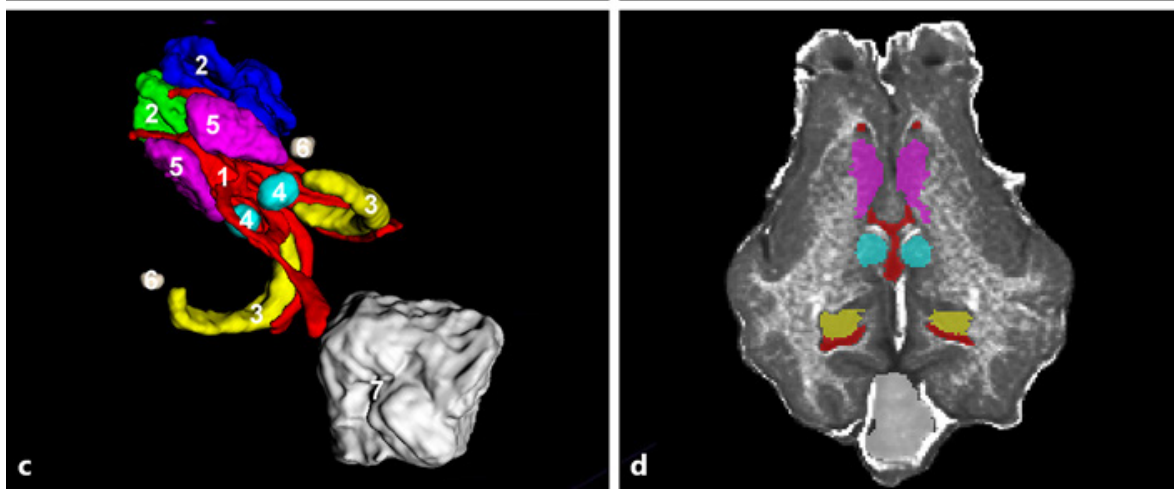

\section{Influence of Anaesthesia during MRI}

Anaesthesia is also known to modify the cerebral hemodynamic, the glucose metabolic rate, the neuronal activity, and the neurovascular coupling, and it has an impact on BOLD fMRI usually used to detect and map brain activation [9]. Among the different anaesthetics used in sheep, inhaled ones like halothane, fluothane, and isoflurane are the most commonly used for long neurosurgery [10] because the doses are easily adapted from 1 to $3 \%$ under assisted ventilation. However, isoflurane induceddeep anaesthesia in rat decreases BOLD response but it has no effect if the animals were ventilated [9]. In spontaneously breathing rabbits, isoflurane and fentanyl alone decreased BOLD response magnitude, and the decrease is more important when both anaesthetics are used [11]. These data indicate that not only the type of anaesthesia is important but also the way they are administered, is important too. In large animals like sheep, the impact of inhaled anaesthesia was recently studied, and it was shown that low doses of isoflurane delivered through a respirator give reliable results on a model of BOLD fMRI under visual stimuli in lambs and ewes [12]. The authors observed robust BOLD response in the lateral geniculate nuclei after visual stimuli, and this effect is weaker in adults than in lambs. Telazol another anaesthetic, non- narcotic, and nonbarbiturate injectable compound was also successfully used for BOLD fMRI in sheep submitted to external tactile and visual stimuli, to map the sensorimotor and visual areas of the sheep brain [13]. In the same study, DTI tractography was successfully used to visualize the corticospinal tracts and optic radiations in sheep, and the data were qualitatively comparable to those obtain from healthy human adults [13]. Isoflurane appears to be used in most of fMRI studies performed in sheep in various protocols like to measure perfusion deficit in a stroke model [14], to study progressive degenerative in Batten disease [15] or to investigate foetal cerebral lesions induced by long-term exposure to cocaine during sheep pregnancy [16].

\section{Atlases Development}

In parallel to the development of suitable protocols for anaesthesia, specific sheep brain templates and atlases have been built for analysing the MRI images of sheep brain and properly identified brain structure [17-22]. Identification and segmentation of brain structures were manually or automatically performed using tools previously prepared for human analysis pictures and adapted to sheep as illustrated on Figure 1. When compared to classical brain atlases built with histological tools, the an- 
atomical resolution is lower, in a millimetre range. The voxel size is about $0.5 \times 0.5 \times 0.5 \mathrm{~mm}$ with the scanner used (3T) and such anatomical resolution make difficult the identification of small hypothalamic nuclei like the arcuate nucleus. Higher resolution will be possible with $7 \mathrm{~T}$ or $11 \mathrm{~T}$ scanner when they will be available for large animals.

\section{Sheep Model in Neuroendocrinology}

In sheep, the pituitary is large, and the stalk is long like in human which makes that the pituitary is not closed to the hypothalamus like in rodents but clearly separated like in human. The anterior part of the gland and the pituitary stalk is surrounded by a particularly dense network of small blood vessels. These morphological characteristics make blood sampling available and several millilitres of blood samples can be collected for several hours, allowing the study of neurohormone kinetic release. This approach was developed by Caraty et al. [23] to demonstrate for the first time that Gonadotrophin Releasing Hormone $(\mathrm{GnRH})$ was released in a pulsatile manner in the hypophysial portal blood. Using this technique in parallel with peripheral blood sampling in rams, the authors showed that GnRH release in the hypophyseal portal blood mirrors the LH release in the general circulation [24]. Other hypothalamic neurohormones are available with this approach such as Corticotrophin Releasing Hormone [25], vasopressin [25, 26], somatostatin [27], Growth Hormone Releasing Hormone [28], Thyrotrophin Releasing Hormone [29] and more recently discovered peptides like Kisspeptide [30, 31] and Gonadotrophin Inhibiting Hormone [32]. It is noteworthy that all these experiments were performed on conscious and unrestrained animals. For GnRH, Corticotrophin Releasing Hormone, and vasopressin, the portal neuropeptide release mirrors the peripheral release of the $\mathrm{LH}$ and adrenocorticotrophic hormone, respectively [24, 25]. For TRH, somatostatin, Growth Hormone Releasing Hormone, and Gonadotrophin Inhibiting Hormone, the studies show a more complex regulation that initially hypothesized.

According to the large size of the sheep brain compared to rodents or small nonhuman primates it is easy to identify neuronal nuclei and to characterize the neuronal target of peripheral hormones. For example, the presence of androgen receptors has been carefully described in the brain of sheep [33] in different neuronal population of hypothalamus and adjacent areas, more particularly in

Magnetic Resonance Imaging for

Neuroendocrine Research in Sheep the somatostatin containing neurones of ventromedial hypothalamic nucleus [34]. Estradiol action sites were identified using 17 beta-estradiol microimplants positioned in the medial preoptic area or the $\mathrm{MBH}$ of ovariectomized ewes. Only the microimplants in the $\mathrm{MBH}$ were able to induce a normal LH surge [35]. Later on, the presence of estradiol receptor alpha and receptor beta was described using immunohistochemistry in the hypothalamus of ewes [36-38], and in the brainstem in noradrenergic neurones [39, 40]. Using immunohistochemistry, the presence of glucocorticoids receptors was demonstrated in the hippocampus [41] and in the hypothalamus of ewes [42] but not in GnRH neurones [43].

Because sheep are seasonal breeders, melatonin is another key regulator of the gonadotrop axis. The central nuclei sensitive to this hormone were identified in the premammillary area of the hypothalamus using autoradiography with ${ }^{125}$ I-labelled melatonin and the stimulatory effect on LH secretion induced by microimplant of melatonin placed in the same area $[44,45]$. All these areas have a millimetre size allowing easier experimental and analytical approach than in rodents.

In the field of neuroendocrine control of reproduction, a pioneering MRI analysis were made in castrated ram treated with zeranol, a non-steroidal oestrogen analogue previously used in cattle to stimulate growth through the secretion of GH [46]. Using a $0.5 \mathrm{~T}$ scanner, the authors observed that the pituitary gland increased 3 time greater in zeranol treated animals than in controls. More recently, additional studies were developed to investigate the role of sexual steroids on the brain using more powerful scanners.

\section{Brain Imaging and Sex Steroids Effects on the Sheep Brain}

The effect of gonadal steroids on the morphological and functional brain sexual dimorphism has been studied in adult sheep using in vivo MRI [47]. Scanning was performed during the breeding season first on intact animals and then after gonadal removal on the same animals. Using Voxel-based Morphometry data processing, the authors identified 37 sexual dimorphic structures in intact animals, which are also dimorphic in human, such amygdala, hippocampus, hypothalamus, and pituitary $[48,49]$. Gray matter volume is higher in the hypothalamus of male as observed in men [50], but the pituitary is smaller in female as observed in women [51]. After removal of the gonads, 22 structures were still dimorphic, but the gray 


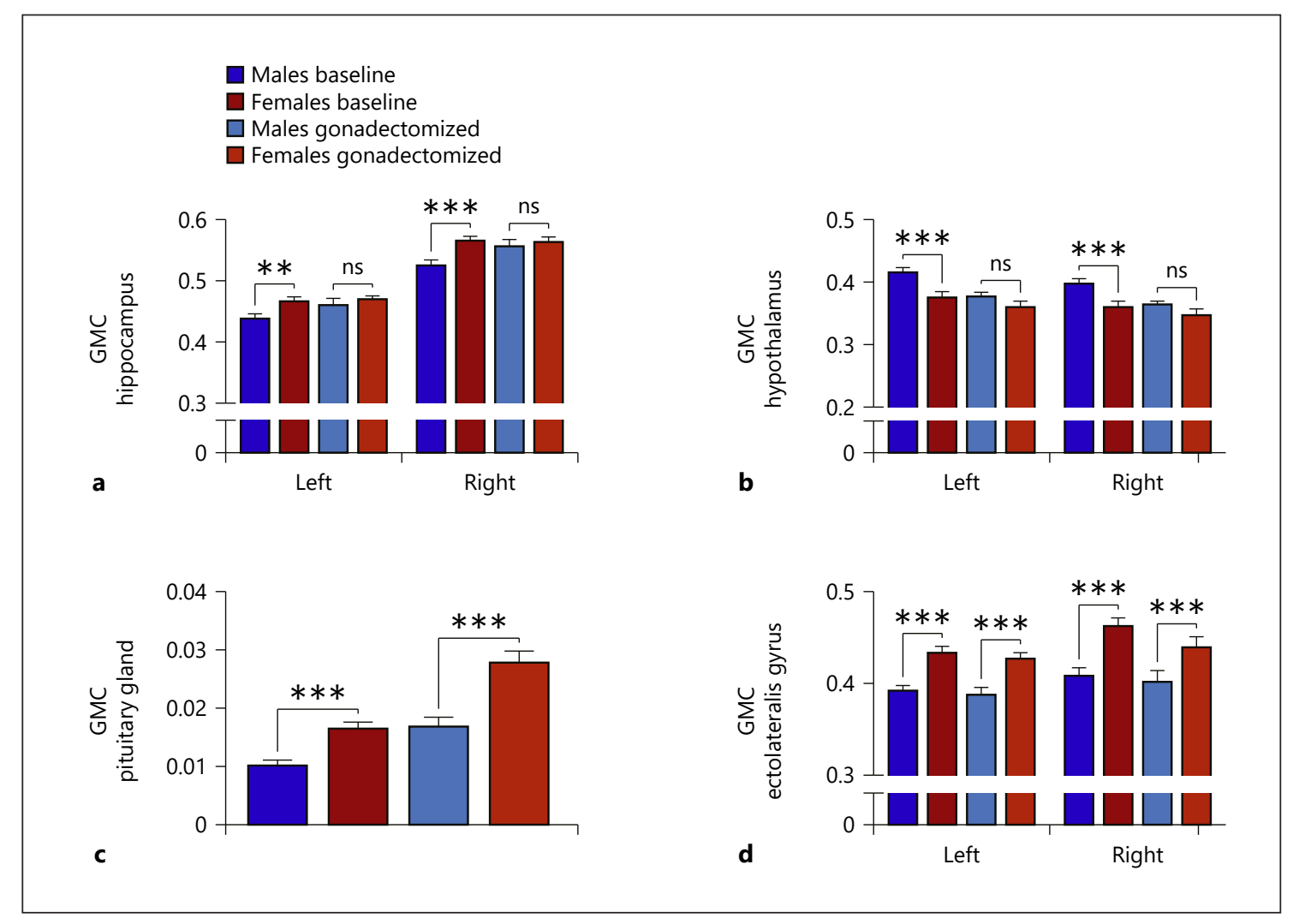

Fig. 2. Effect of gonadectomy on sexually dimorphic structures. The mean values of GMC were evaluated bilaterally in hippocampus (a), hypothalamus (b), pituitary gland (c) and ectolateralis gyrus for both male and female sheep before and after gonadectomy. Data were compared using a two-way ANOVA followed by Holm-
Sidak multiple comparisons test and expressed as mean \pm SEM; ${ }^{*} p$ $<0.05{ }^{* *} p<0.01$, and ${ }^{* * *} p<0.001 . N=20$ animals ( 8 males and 12 females) from Barrière et al. [47]. GMC, grey matter concentration.

According to the sex differences on physiological and cognitive parameters observed in sheep $[57,58]$, the role of reproductive axis on brain structures related to emotion were investigated in sheep brain using MRI. The experiments were performed in young male and female sheep treated with a GnRH agonist to stop the production of gonadal hormones and to block pubertal development [59]. Previous studies in sheep shown that this compound has also a sex specific effect on behaviour and emotion regulation [60]. Fixed brain were analysed ex vivo with a 3T scanner, focusing on the volume of amygdala, hippocampus, and total brain. The authors showed that blockade of gonadal axis and puberty induced an increase of the size of amygdala in treated animals, the effect being stronger in female compared to male, no effect was observed in the hippocampus. The sexual dimorphism observed in the amygdala in sheep by Nuruddin et al. [59] was also observed by Barrière et al. [47] and in human [49]. Sexual dimorphism of the hippocampus was observed by Barri- 
ère et al. [61] in sheep but remains controversial in human, it would be larger in girls compared to boys only during adolescence [62]. The authors observed in sheep a global gray matter volume larger in male than in female as observed in human by Peper et al. [63]. These results underlined that the lamb treated with GnRH agonist is a suitable model to study more deeply the role of this analogue used to treat precocious puberty in children [64].

\section{Conclusion}

This short review underlines that MRI analysis with 3T clinical MRI scanner is now possible in sheep, a good model for neuroendocrine control of reproduction and cognition and that it gives new and original data in the field of neuroendocrinology as already shown in the field of neuropathology [65-70]. In the field of neuroendocrinology, MRI will strengthen the use of ewes as a model of neuroendocrine aspect of PCOS, the most important disorder of woman reproduction for which ewes would be a suitable animal model. Androgenisation of ewes during gestation gives birth to females that present PCOS traits [71-73]. Using MRI, it will be now possible to study the central aspect of the syndrome as previously described in mice [74] and for which woman studies remains limited for ethical reasons [75]. According to its physiological and developmental features, sheep are also suitable model for the study of endocrine disruptor, and their impact on foetal development and on brain development [76]. MRI is now available to study in sheep these emergent disorders and emphasize the importance of this model.

The limits of these studies are the availability of complete anatomical atlas of the sheep brain and appropriate templates for the identification of brain areas, especially for cortical and subcortical structures. Some atlases were already prepared by various laboratories [17-22] and are suitable for the identification of numerous brain areas even though they are less accurately described than in rodents and human. Additional anatomical studies of the sheep brain will be necessary. MRI analysis will give new opportunities for using sheep as a model for studying neuroendocrine interactions in the field of human pathology of reproduction in addition to academic research.

\section{Conflict of Interest Statement}

The author has no conflicts of interest to declare.

\section{Funding Sources}

No funding was received to support this work.

\section{Author Contributions}

Yves Tillet analysed the literature and wrote the manuscript.

\section{References}

1 Rasgon NL, Silverman D, Siddarth P, Miller K, Ercoli LM, Elman S, et al. Estrogen use and brain metabolic change in postmenopausal women. Neurobiol Aging. 2005;26: 229-35.

2 Maki PM, Resnick SM. Longitudinal effects of estrogen replacement therapy on PET cerebral blood flow and cognition. Neurobiol Aging. 2000;21:373-83.

3 Ottowitz WE, Dougherty DD, Fischman AJ, Hall JE. [18F] 2-fluoro-2-deoxy-D-glucose positron emission tomography demonstration of estrogen negative and positive feedback on luteinizing hormone secretion in women. J Clin Endocrinol Metab. 2008 Aug; 93(8):3208-14.

4 Baroncini M, Jissendi P, Catteau-Jonard S, Dewailly D, Pruvo JP, Francke JP, et al. Sex steroid hormones-related structural plasticity in the human hypothalamus. Neuroimage. 2010 Apr 1;50(2):428-33.

5 Chaillou E, Tillet Y, Andersson F. MRI techniques and new animal models for imaging the brain. In: Mantamadiotis $\mathrm{T}$, editors. When things go wrong: diseases and disorders of the human brain. London: InTech; 2012;(Chapitre 10); p. 207-31.

6 Clarke IJ, Doughton BW. Effect of various anaesthetics on resting plasma concentrations of luteinizing hormone, follicle-stimulating hormone and prolactin in ovariectomized ewes. J Endocrinol. 1983 Jul;98(1):7989.

7 Goodman RL, Meyer SL. Effects of pentobarbital anesthesia on tonic luteinizing hormone secretion in the ewe: evidence for active inhibition of luteinizing hormone in anestrus. Biol Reprod. 1984 Mar;30(2):37481.

8 Gil AG, Silván G, Illera JC. Pituitary-adrenocortical axis, serum serotonin and biochemical response after halothane or isoflurane anaesthesia in rabbits. Lab Anim. 2007 Oct; 41(4):411-9.

9 van Alst TM, Wachsmuth L, Datunashvili M, Albers F, Just N, Budde T, et al. Anesthesia differentially modulates neuronal and vascular contributions to the BOLD signal. NeuroImage. 2019;195:89-103.

10 Tillet Y, Batailler M, Thibault J. Neuronal projections to the medial preoptic area of the sheep, with special reference to monoaminergic afferents: Immunohistochemical and Retrograde Tract Tracing Studies. J Comp Neurol. 1993;330:195-220.

11 Aksenov DP, Li L, Miller MJ, Iordanescu G, Wyrwicz AM. Effects of anesthesia on BOLD signal and neuronal activity in the somatosensory cortex. J Cereb Blood Flow Metab. 2015 Nov;35(11):1819-26.

12 Just N, Adriaensen H, Ella A, Chevillard PM, Batailler M, Dubois JP, et al. Blood oxygen level dependent fMRI and perfusion MRI in the sheep brain. Brain Res. 2021 Jun 1;1760: 147390.

13 Lee W, Lee SD, Park MY, Foley L, PurcellEstabrook E, Kim H, et al. Functional and diffusion tensor magnetic resonance imaging of the sheep brain. BMC Vet Res. 2015;11:262.
Magnetic Resonance Imaging for

Neuroendocrine Research in Sheep
Neuroendocrinology 2023;113:208-215 DOI: $10.1159 / 000522087$ 
14 Herrmann AM, Cattaneo GFM, Eiden SA, Wieser M, Kellner E, Maurer C, et al. Development of a routinely applicable imaging protocol for fast and precise middle cerebral artery occlusion assessment and perfusion deficit measure in an ovine stroke model: a Case Study. Front Neurol. 2019 Nov 14;10:1113.

15 Sawiak SJ, Perumal SR, Rudiger SR, Matthews L, Mitchell NL, McLaughlan CJ, et al. Rapid and progressive regional brain atrophy in CLN6 batten disease affected sheep measured with longitudinal magnetic resonance imaging. PLoS One. 2015 Jul 10;10(7):e0132331.

16 Akoka S, Descamps P, Genberg C, Franconi F, Arbeille B, Laurini R, et al. Cerebral MRI on fetuses submitted to repeated cocaine administration during the gestation: an ovine model. Eur J Obstet Gynecol Reprod Biol. 1999 Aug;85(2):185-90.

17 Staudacher A, Oevermann A, Stoffel MH, Gorgas D. Validation of a magnetic resonance imaging guided stereotactic access to the ovine brainstem. BMC Vet Res. 2014 Sep 22; 10:216.

18 Nitzsche B, Frey S, Collins LD, Seeger J, Lobsien D, Dreyer A, et al. A stereotaxic, population-averaged $\mathrm{T} 1 \mathrm{w}$ ovine brain atlas including cerebral morphology and tissue volumes. Front Neuroanat. 2015 Jun 4;9:69.

19 Ella A, Keller M. Construction of an MRI 3D high resolution sheep brain template. Magn Reson Imaging. 2015 Dec;33(10):1329-37.

20 Liyanage KA, Steward C, Moffat BA, Opie NL, Rind GS, John SE, et al. Development and implementation of a corriedale ovine brain atlas for use in atlas-based segmentation. PLoS One. 2016 Jun 10;11(6):e0155974.

21 Ella A, Delgadillo JA, Chemineau P, Keller M. Computation of a high-resolution MRI 3D stereotaxic atlas of the sheep brain. J Comp Neurol. 2017 Feb 15;525(3):676-92.

22 Pieri V, Trovatelli M, Cadioli M, Zani DD, Brizzola S, Ravasio $G$, et al. In vivo diffusion tensor magnetic resonance tractography of the sheep brain: an atlas of the ovine white matter fiber bundles. Front Vet Sci. 2019 Oct $16 ; 6: 345$.

23 Caraty A, Orgeur P, Thiery JC. Demonstration of the pulsatile secretion of LH-RH into hypophysial portal blood of ewes using an original technic for multiple samples. C R Seances Acad Sci III. 1982 Sep 20;295(2):103-6.

24 Caraty A, Locatelli A. Effect of time after castration on secretion of LHRH and LH in the ram. J Reprod Fertil. 1988 Jan;82(1):263-9.

25 Caraty A, Grino M, Locatelli A, Oliver C. Secretion of corticotropin releasing factor (CRF) and vasopressin (AVP) into the hypophysial portal blood of conscious, unrestrained rams. Biochem Biophys Res Commun. 1988 Sep 15;155(2):841-9.

26 Battaglia DF, Brown ME, Krasa HB, Thrun LA, Viguié C, Karsch FJ. Systemic challenge with endotoxin stimulates corticotropin-releasing hormone and arginine vasopressin secretion into hypophyseal portal blood: coincidence with gonadotropin-releasing hor- mone suppression. Endocrinology. 1998 Oct; 139(10):4175-81.

27 Veldhuis JD, Fletcher TP, Gatford KL, Egan AR, Clarke IJ. Hypophyseal-portal somatostatin (SRIH) and jugular venous growth hormone secretion in the conscious unrestrained ewe. Neuroendocrinology. 2002 Feb;75(2): 83-91.

28 Fletcher TP, Thomas GB, Clarke IJ. Growth hormone-releasing hormone and somatostatin concentrations in the hypophysial portal blood of conscious sheep during the infusion of growth hormone-releasing peptide- 6 . Domest Anim Endocrinol. 1996 May;13(3): 251-8.

29 Dahl GE, Evans NP, Thrun LA, Karsch FJ. A central negative feedback action of thyroid hormones on thyrotropin-releasing hormone secretion. Endocrinology. 1994 Dec;135(6): 2392-7.

30 Smith JT, Rao A, Pereira A, Caraty A, Millar $\mathrm{RP}$, Clarke IJ. Kisspeptin is present in ovine hypophysial portal blood but does not increase during the preovulatory luteinizing hormone surge: evidence that gonadotropes are not direct targets of kisspeptin in vivo. Endocrinology. 2008 Apr;149(4):1951-9.

31 Caraty A, Lomet D, Sébert ME, Guillaume D, Beltramo M, Evans NP. Gonadotrophin-releasing hormone release into the hypophyseal portal blood of the ewe mirrors both pulsatile and continuous intravenous infusion of kisspeptin: an insight into kisspeptin's mechanism of action. J Neuroendocrinol. 2013 Jun; 25(6):537-46.

32 Smith JT, Young IR, Veldhuis JD, Clarke IJ. Gonadotropin-inhibitory hormone ( $\mathrm{GnIH})$ secretion into the ovine hypophyseal portal system. Endocrinology. 2012 Jul; 153(7): 3368-75.

33 Scott CJ, Clarke IJ, Rao A, Tilbrook AJ. Sex differences in the distribution and abundance of androgen receptor mRNA-containing cells in the preoptic area and hypothalamus of the ram and ewe. J Neuroendocrinol. 2004 Dec; 16(12):956-63.

34 Herbison AE, Skinner DC, Robinson JE, King IS. Androgen receptor-immunoreactive cells in ram hypothalamus: distribution and colocalization patterns with gonadotropin-releasing hormone, somatostatin and tyrosine hydroxylase. Neuroendocrinology. 1996 Feb; 63(2):120-31.

35 Caraty A, Fabre-Nys C, Delaleu B, Locatelli A, Bruneau G, Karsch FJ, et al. Evidence that the mediobasal hypothalamus is the primary site of action of estradiol in inducing the preovulatory gonadotropin releasing hormone surge in the ewe. Endocrinology. 1998 Apr;139(4): 1752-60.

36 Blache D, Batailler M, Fabre-Nys C. J Oestrogen receptors in the preoptico-hypothalamic continuum: immunohistochemical study of the distribution and cell density during induced oestrous cycle in ovariectomized ewe. Neuroendocrinology. 1994 Jun; 6(3):329-39.
37 Skinner DC, Dufourny L. Oestrogen receptor beta-immunoreactive neurones in the ovine hypothalamus: distribution and colocalisation with gonadotropin-releasing hormone. J Neuroendocrinol. 2005 Jan;17(1):29-39.

38 Lehman MN, Ebling FJ, Moenter SM, Karsch FJ. Distribution of estrogen receptor-immunoreactive cells in the sheep brain. Endocrinology. 1993 Aug;133(2):876-86.

39 Simonian SX, Delaleu B, Caraty A, Herbison AE. Estrogen receptor expression in brainstem noradrenergic neurons of the sheep. Neuroendocrinology. 1998 Jun;67(6):392402.

40 Scott CJ, Rawson JA, Pereira AM, Clarke IJ. Oestrogen receptors in the brainstem of the female sheep: relationship to noradrenergic cells and cells projecting to the medial preoptic area. J Neuroendocrinol. 1999 Oct;11(10): 745-55.

41 Sloboda DM, Moss TJ, Li S, Matthews SG, Challis JR, Newnham JP. Expression of glucocorticoid receptor, mineralocorticoid receptor, and 11 beta-hydroxysteroid dehydrogenase 1 and 2 in the fetal and postnatal ovine hippocampus: ontogeny and effects of prenatal glucocorticoid exposure. J Endocrinol. 2008 May;197(2):213-20.

42 Dufourny L, Skinner DC. Progesterone receptor, estrogen receptor alpha, and the type II glucocorticoid receptor are coexpressed in the same neurons of the ovine preoptic area and arcuate nucleus: a Triple Immunolabeling Study. Biol Reprod. 2002 Nov;67(5): 1605-12.

43 Dufourny L, Skinner DC. Type II glucocorticoid receptors in the ovine hypothalamus: distribution, influence of estrogen and absence of co-localization with GnRH. Brain Res. 2002 Aug 9;946(1):79-86.

44 Malpaux B, Daveau A, Maurice-Mandon F, Duarte G, Chemineau P. Evidence that melatonin acts in the premammillary hypothalamic area to control reproduction in the ewe: presence of binding sites and stimulation of luteinizing hormone secretion by in situ microimplant delivery. Endocrinology. 1998 Apr;139(4):1508-16

45 Sliwowska JH, Billings HJ, Goodman RL, Coolen LM, Lehman MN. The premammillary hypothalamic area of the ewe: anatomical characterization of a melatonin target area mediating seasonal reproduction. Biol Reprod. 2004 Jun;70(6):1768-75.

46 Carroll JA, Walker MA, Hartsfield SM, McArthur NH, Welsh TH Jr. Visual documentation of ovine pituitary gland development with magnetic resonance imaging following zeranol treatment. Lab Anim. 2007 Jan;41(1):120-7.

47 Barrière DA, Ella $\mathrm{A}$, Adriaensen $\mathrm{H}$, Roselli $\mathrm{CE}$, Chemineau $\mathrm{P}$, Keller M. In vivo magnetic resonance imaging reveals the effect of gonadal hormones on morphological and functional brain sexual dimorphisms in adult sheep. Psychoneuroendocrinology. 2019 Nov; 109:104387. 
48 Goldstein JM, Seidman LJ, Horton NJ, Makris N, Kennedy DN, Caviness VS Jr, et al. Normal sexual dimorphism of the adult human brain assessed by in vivo magnetic resonance imaging. Cereb Cortex. 2001 Jun;11(6):490-7.

49 Lotze M, Domin M, Gerlach FH, Gaser C, Lueders E, Schmidt CO, et al. Novel findings from 2,838 adult brains on sex differences in gray matter brain volume. Sci Rep. $2019 \mathrm{Feb}$ 8;9(1):1671.

50 Makris N, Swaab DF, van der Kouwe A, Abbs B, Boriel D, Handa RJ, et al. Volumetric parcellation methodology of the human hypothalamus in neuroimaging: normative data and sex differences. Neuroimage. 2013 Apr 1; 69:1-10.

51 Pecina HI, Pecina TC, Vyroubal V, Kruljac I, Slaus M. Age and sex related differences in normal pituitary gland and fossa volumes. Front Biosci (Elite Ed). 2017 Mar 1;9:204-13.

52 Swaab DF, Gooren LJ, Hofman MA. The human hypothalamus in relation to gender and sexual orientation. Prog Brain Res. 1992;93: 205-9; discussion 217-219.

53 Ossewaarde L, van Wingen GA, Rijpkema M, Bäckström T, Hermans EJ, Fernández G. Menstrual cycle-related changes in amygdala morphology are associated with changes in stress sensitivity. Hum Brain Mapp. 2013 May;34(5):1187-93.

54 Kruijver FP, Balesar R, Espila AM, Unmehopa UA, Swaab DF. Estrogen receptor-alpha distribution in the human hypothalamus in relation to sex and endocrine status. J Comp Neurol. 2002 Dec 9;454(2):115-39.

55 Kruijver FP, Balesar R, Espila AM, Unmehopa UA, Swaab DF. Estrogen-receptor-beta distribution in the human hypothalamus: similarities and differences with ER alpha distribution. J Comp Neurol. 2003 Nov 10; 466(2):251-77.

56 Pletzer B, Harris TA, Scheuringer A, HidalgoLopez E. The cycling brain: menstrual cycle related fluctuations in hippocampal and fronto-striatal activation and connectivity during cognitive tasks. Neuropsychopharmacology. 2019 Oct;44(11):1867-75.

57 Skinner DC, Albertson AJ, Navratil A, Smith A, Mignot M, Talbott $\mathrm{H}$, et al. Effects of gonadotrophin-releasing hormone outside the hypothalamic-pituitary-reproductive axis. J Neuroendocrinol. 2009 Mar;21(4):282-92.
58 Evans NP, Robinson JE, Erhard HW, Ropstad E, Fleming LM, Haraldsen IR. Development of psychophysiological motoric reactivity is influenced by peripubertal pharmacological inhibition of gonadotropin releasing hormone action--results of an ovine model. Psychoneuroendocrinology. 2012 Nov;37(11): 1876-84.

59 Nuruddin S, Nuruddin S, Bruchhage M, Ropstad E, Krogenæs A, Evans NP, et al. Effects of peripubertal gonadotropin-releasing hormone agonist on brain development in sheep: a Magnetic Resonance Imaging Study. Psychoneuroendocrinology. 2013 Oct;38(10): 1994-2002.

60 Wojniusz S, Callens N, Sütterlin S, Andersson S, De Schepper J, Gies I, et al. Cognitive, emotional, and psychosocial functioning of girls treated with pharmacological puberty blockage for idiopathic central precocious puberty. Front Psychol. 2016 Jul 12;7:1053.

61 Tan A, Ma W, Vira A, Marwha D, Eliot L, The human hippocampus is not sexually-dimorphic: meta-analysis of structural MRI volumes. Neuroimage. 2016;124(Pt A):350-66.

62 Neufangr S, Specht K, Hausmann M, Güntürkün $\mathrm{O}$, Herpertz-Dahlmann B, Fink GR, et al. Sex differences and the impact of steroid hormones on the developing human brain. Cereb Cortex. 2009 Feb;19(2):464-73.

63 Peper JS, Hulshoff Pol HE, Crone EA, van Honk J. Sex steroids and brain structure in pubertal boys and girls: a Mini-Review of Neuroimaging Studies. Neuroscience. 2011 Sep 15;191:28-37.

64 Carel JC, Eugster EA, Rogol A, Ghizzoni L, Palmert MR; ESPE-LWPES GnRH Analogs Consensus Conference Group, et al. Consensus statement on the use of gonadotropin-releasing hormone analogs in children. Pediatrics. 2009 Apr;123(4):e752-62.

65 O'Connell AB, Kuchel TR, Perumal SR, Sherwood V, Neumann D, Finnie JW, et al. Longitudinal magnetic resonance spectroscopy and diffusion tensor imaging in sheep (ovis aries) with quinolinic acid lesions of the striatum: time-dependent recovery of $\mathrm{N}$-acetylaspartate and fractional anisotropy. J Neuropathol Exp Neurol. 2020 Oct 1;79(10):108492.

66 Kaiser EE, West FD. Large animal ischemic stroke models: replicating human stroke pathophysiology. Neural Regen Res. 2020 Aug;15(8):1377-87.
67 Sorby-Adams AJ, Leonard AV, Elms LE, Marian OC, Hoving JW, Yassi N, et al. Determining the temporal profile of intracranial pressure changes following transient stroke in an ovine model. Front Neurosci. 2019 Jul 9;13: 587.

68 Mitchell NL, Russell KN, Wellby MP, Wicky HE, Schoderboeck L, Barrell GK, et al. Longitudinal in vivo monitoring of the CNS demonstrates the efficacy of gene therapy in a sheep model of CLN5 batten disease. Mol Ther. 2018 Oct 3;26(10):2366-78.

69 Gray-Edwards HL, Randle AN, Maitland SA, Benatti HR, Hubbard SM, Canning PF, et al. Adeno-associated virus gene therapy in a sheep model of tay-sachs disease. Hum Gene Ther. 2018 Mar;29(3):312-26.

70 Stypulkowski PH, Giftakis JE, Billstrom TM. Development of a large animal model for investigation of deep brain stimulation for epilepsy. Stereotact Funct Neurosurg. 2011; 89(2):111-22. Epub $2011 \mathrm{Feb} 17$.

71 West C, Foster DL, Evans NP, Robinson J, Padmanabhan V. Intra-follicular activin availability is altered in prenatally-androgenized lambs. Mol cell endocrinol. 2001;185: 51-9.

72 Hogg K, Young JM, Oliver EM, Souza CJ, McNeilly AS, Duncan WC. Enhanced thecal androgen production is prenatally programmed in an ovine model of polycystic ovary syndrome. Endocrinology. 2012;153(1):450-61.

73 Stener-Victorin E, Padmanabhan V, Walters KA, Campbell RE, Benrick A, Giacobini P, et al. Animal models to understand the etiology and pathophysiology of polycystic ovary syndrome. Endocr Rev. 2020 Jul 1;41(4). bnaa010.

74 Cimino I, Casoni F, Liu X, Messina A, Parkash J, Jamin SP, et al. Novel role for anti-Müllerian hormone in the regulation of GnRH neuron excitability and hormone secretion. Nat Commun. 2016 Jan 12;7:10055.

75 Lai W, Li X, Zhu H, Zhu X, Tan H, Feng P, et al. Plasma luteinizing hormone level affects the brain activity of patients with polycystic ovary syndrome. Psychoneuroendocrinology. 2020 Feb;112:104535. Epub 2019 Nov 28.

76 Viguié C, Chaillou E, Gayrard V, Picard-Hagen N, Fowler PA. Toward a better understanding of the effects of endocrine disrupting compounds on health: Human-relevant case studies from sheep models. Mol Cell Endocrinol. 2020 Apr 5;505:110711. Epub 2020 Jan 16.
Magnetic Resonance Imaging for

Neuroendocrine Research in Sheep
Neuroendocrinology 2023;113:208-215

DOI: $10.1159 / 000522087$ 